\title{
Soft and Dry Phenotypes of Date Palms (Phoenix dactylifera $L$.): Resources for Selection and Indicators for Adaptation
}

\author{
Sakina Elshibli ${ }^{1}$, Elshibli Mohamed Elshibli ${ }^{2}$ and Helena Korpelainen ${ }^{1}$ \\ ${ }^{1}$ Department of Agricultural Sciences, University of Helsinki, Finland \\ ${ }^{2}$ Department of Applied Statistics, Al Neelain University, Sudan
}

Submission: February 06, 2017; Published: March 30, 2017

*Corresponding author: Sakina Elshibli, Department of Agricultural Sciences, Viikki Plant Science Centre, P. O. Box 27, FI-00014 University of Helsinki, Finland; Email: sakina.elshibli@helsinki.fi

\begin{abstract}
Soft, dry and intermediate types of date palm fruits have been defined for decades as resources for wide range of fruit qualities specified by chemical composition of dates. Traits of groups of fruit qualities have been reflected in detectable differentiation at morphological as well as genetic levels. In this work we defined sampled groups of cultivars as soft and dry phenotypes and considered testing their growth and photosynthetic $\mathrm{CO}_{2}$ response to water availability. The experiment executed under controlled conditions. Water availability tested at field capacity (FC) from $10 \%$ to $100 \%$. Basic statistics, principal component analysis and biochemical gas exchange model were employed to measure different responses. Analysed data revealed differences in response among phenotypes increased with the increase of water shortage especially a noticeable mediated variance in growth traits: the root fresh weight, root/shoot ratio and biomass. An interaction effect of phenotype $\times$ water treatments was also detected for root dry weight $(\mathrm{p}<0.05)$ and number of pinnae $(\mathrm{p}<0.01)$. At $10 \% \mathrm{FC}$ the photosynthesis of soft types was significantly $(p<0.01)$ higher compared to dry types explained by the differences in the capacity of stomatal conductance (gs) as well as biochemical reaction parameters. We suggest soft and dry types of cultivars to possess functional specific traits with a possible role for phenotype-specific adaptation to different environments. Soft and dry phenotypes as grouping pattern to be further considered for research for selection criteria and indicators for drought adaptation especially when new lands/regions to enter date palm culture.
\end{abstract}

Keywords: Phoenix dactylifera L; Soft cultivars; Dry cultivars; Water availability; Growth traits; Photosynthesis; Gas exchange

\section{Introduction}

Date palm species through its long domestication in history emerged with wide range of diversity. This diversity enriched by locally developed cultivars or races, elite varieties as well as genotypes that structured to geographical regions and different environments [1]. The distribution and performance of different date palm cultivars, as classified into soft and dry types, is considerably affected by the geographic location [2,3]. Clear differences were reported in fruit characters and tree morphology between the two phenotypes [3-5].

The defined criteria of soft and dry types of date palm fruits are strongly presented in date palm production in Sudan. Chemical composition of fruits of wide range of Sudanese cultivars been characterized and reported [6]. Geographic distribution of phenotypes following the gradual changes of environments especially the degree of aridity. Generally, the production regions of date fruits in Sudan can be classified as for soft or dry types of dates with transitional locality in between [7]. Reasons for this kind of geographic distribution, among others, include the time of rainy season as related to yield management. However, genetic differentiation reported among soft and dry phenotypes at molecular level [7]. Genetic structuring of plant species may provide evidences for endurance and adaptation to environment as interaction consequence. On the other hand, adaptive traits are traceable through strategic responses to influencing factors. Plant strategies to cope low water availability reflected in a range of traits among which shoot and root growth [8-10] as well as indices that measure photosynthesis [11].

In Elshibli et al. [12] we described in general the effect of water availability to photosynthetic $\mathrm{CO}_{2}$ and growth responses of date palm plants. At cultivar level there were no specific responses 
observed, however, some interaction effects were detected. In this study, we focused on cultivars as soft and dry phenotypes. We aimed to evaluate shoot and root growth as well as alterations in photosynthetic capacity to water availability and to detect which traits may underlie the differences among these ecologically distinct groups.

\section{Materials and Methods}

\section{Plant material and experimental layout}

Date palm plants of the half-sibs cultivars Gondaila, Barakawi and Bitamoda considered for dry types; seeds initially collected from the Nori Horticultural Orchard in Sudan (18 $32^{\prime} 45^{\prime \prime} \mathrm{N}$; $31^{\circ} 54^{\prime}$ 15" E;), and Mishrig Wad Laggai (Laggai) and Mishrig Wad Khateeb (Khateeb) considered for soft types; seeds initially collected from a farmer's orchard in Elbaoga in Sudan (18 $17^{\prime} 45^{\prime \prime}$ N; $33^{\circ} 54^{\prime} 30^{\prime \prime}$ E;). Full description of the chemical composition of fruits of each cultivar as related to each phenotype was reported by [6]. Date palm plants raised in green house; growth conditions, watering and soil composition detailed in [12]. Water treatments were subjected to one-year old plants of each cultivar, in a randomized complete block design with two factors consisting of five cultivars (two phenotypes) and four watering regimes: 100\%, 50\%, 25\% and $10 \%$ field capacity (FC). Treatments were replicated four times. To compensate for water loss at each treatment and retain different measurements of field capacity, plants were weighed and watered twice a week in the morning. Evaporation from the soil surface was minimized by enclosing the pots in plastic bags at soil level. The experimental treatments lasted for six months, during which the plants were circulated once every 2-3 weeks to avoid errors due to possible differences in the controlled growth conditions.

\section{Gas-exchange measurements}

CIRAS2 portable photosynthesis measurement system (PP Systems, Hitchin, Hertfordshire, UK) was employed to carry out gas exchange measurements. Leaf temperature was adjusted to $25^{\circ} \mathrm{C}$. Tungsten Halogen light source was used to provide light intensity of above plant light saturation capacity at $1000 \mu \mathrm{mol} \mathrm{m}{ }^{-2} \mathrm{~s}^{-1}$ CIRAS2 was set to provide five observations for each measurement for each level of external supply of $\mathrm{CO}_{2}$ (Ci). Photosynthesis parameters were

Results

\section{Growth traits}

Table 1: Morphological adjustments in soft and dry types of date palm cultivars to water stress.

\begin{tabular}{|c|c|c|c|c|c|c|c|c|c|c|c|c|}
\hline \multicolumn{7}{|c|}{ Dry Types } & \multicolumn{6}{|c|}{ Soft Types } \\
\hline \multicolumn{7}{|c|}{ Water Treatments at Field Capacity } & \multicolumn{6}{|c|}{ Water Treatments at Field Capacity } \\
\hline & $10 \%$ & $25 \%$ & $50 \%$ & $100 \%$ & $\begin{array}{c}\text { ANOVA } \\
\mathrm{P}\end{array}$ & $\begin{array}{l}\text { Pearson's } \\
\text { correlation }\end{array}$ & $10 \%$ & $25 \%$ & $50 \%$ & $100 \%$ & ANOVA P & $\begin{array}{c}\text { Pearson's } \\
\text { correlation }\end{array}$ \\
\hline $\begin{array}{l}\text { Plant } \\
\text { height } \\
\text { (m) }\end{array}$ & $1.28 \mathrm{~b}$ & $1.52 \mathrm{ab}$ & $1.91 \mathrm{a}$ & $1.89 \mathrm{a}$ & $<0.001$ & $0.766^{* *}$ & $1.27 \mathrm{c}$ & $1.76 \mathrm{~b}$ & $2.08 \mathrm{a}$ & $2.21 \mathrm{a}$ & $<0.001$ & $0.788^{* *}$ \\
\hline $\begin{array}{l}\text { Root } \\
\text { fresh } \\
\text { weight } \\
\text { (g) }\end{array}$ & $435 c$ & $1210 b$ & $1361 b$ & $1737 a$ & $<0.001$ & $0.799^{* *}$ & $637 \mathrm{~b}$ & $766 \mathrm{~b}$ & $1697 a$ & $1704 a$ & $<0.05$ & $0.654^{*}$ \\
\hline
\end{tabular}




\begin{tabular}{|c|c|c|c|c|c|c|c|c|c|c|c|c|}
\hline $\begin{array}{l}\text { Shoot } \\
\text { fresh } \\
\text { weight } \\
\text { (g) }\end{array}$ & $661 d$ & $1128 c$ & $1258 b$ & $1638 a$ & $<0.001$ & $0.891^{* *}$ & 694 & 1053 & 1219 & 1409 & n.s. & $0.608^{*}$ \\
\hline $\begin{array}{l}\text { Root dry } \\
\text { weight } \\
\text { (g) }\end{array}$ & 204 & 404 & 373 & 492 & n.s. & $0.532^{*}$ & 257 & 238 & 733 & 421 & n.s. & 0.298 \\
\hline $\begin{array}{c}\text { Shoot } \\
\text { dry } \\
\text { weight } \\
\text { (g) }\end{array}$ & $336 c$ & $499 b$ & $564 \mathrm{ab}$ & $702 a$ & $<0.001$ & $0.851^{* *}$ & 340 & 462 & 520 & 572 & n.s. & 0.529 \\
\hline $\begin{array}{l}\text { No. of } \\
\text { green } \\
\text { leaves }\end{array}$ & $8.2 \mathrm{c}$ & $11.7 \mathrm{~b}$ & $13.5 \mathrm{ab}$ & $13.3 \mathrm{a}$ & $<0.001$ & $0.564^{*}$ & 9 & 9.5 & 11.5 & 10.5 & n.s. & $0.653^{*}$ \\
\hline $\begin{array}{c}\text { No. of } \\
\text { dry } \\
\text { leaves }\end{array}$ & $4.2 \mathrm{a}$ & $0.8 \mathrm{~b}$ & $0.8 \mathrm{~b}$ & $0.9 \mathrm{~b}$ & $<0.01$ & -0.357 & $3.3 \mathrm{a}$ & 3.0ab & $1.0 \mathrm{~b}$ & $1.2 \mathrm{~b}$ & $<0.05$ & $-0.628^{*}$ \\
\hline $\begin{array}{l}\text { No. of } \\
\text { pinnae }\end{array}$ & $247.5 \mathrm{c}$ & 401.2ab & 489.3ab & $485.9 \mathrm{a}$ & $<0.001$ & $0.634^{* *}$ & 284.3 & 317.3 & 291.5 & 350.4 & n.s. & 0.347 \\
\hline $\begin{array}{l}\text { Root/ } \\
\text { shoot } \\
\text { ratio }\end{array}$ & $0.66 b$ & $1.09 a$ & $1.09 a$ & $1.08 \mathrm{a}$ & $<0.05$ & 0.475 & 0.91 & 0.73 & 1.39 & 1.2 & n.s. & 0.412 \\
\hline $\begin{array}{l}\text { Total } \\
\text { biomass } \\
\text { (g) }\end{array}$ & $518 \mathrm{bc}$ & 903ab & $937 a$ & $1194 a$ & $<0.05$ & $0.714^{* *}$ & 576 & 702 & 1253 & 993 & n.s. & 0.429 \\
\hline
\end{tabular}

Data are expressed as means. Within a character for each phenotype, means with the same letters are not significantly different at $p<0.05$ (Duncan's test).

Pearson's correlation; the mean values are significant at ${ }^{*} p<0.01$ and ${ }^{* *} p<0.001$.

Ns: Not Significant.

Table 2:The significance of the effect of different treatments (water, phenotype and their interactions) on morphological traits of the studied plants.

\begin{tabular}{|c|c|c|c|}
\hline Morphological Trait & Water Treatments & Phenotype & Phenotype $\times$ Water Intraction \\
\hline Plant height(m) & $<0.001$ & $<0.05$ & n.s \\
\hline Root fresh weight(g) & $<0.001$ & n.s & n.s \\
\hline Shoot fresh weight $(\mathrm{g})$ & $<0.001$ & n.s & n.s \\
\hline Root dry weight(g) & $<0.05$ & n.s & $<0.05$ \\
\hline Shoot dry weight(g) & $<0.001$ & n.s & n.s \\
\hline No. of green leaves & $<0.001$ & n.s & n.s \\
\hline No. of dry leaves & $<0.001$ & n.s & n.s \\
\hline No. of pinnae & $<0.001$ & $<0.01$ & $<0.01$ \\
\hline Root/shoot ratio & n.s. & n.s & n.s \\
\hline Total biomass(g) & $<0.001$ & n.s & n.s \\
\hline
\end{tabular}

Water treatments resulted in significant changes in plants' growth components (Table 1). Different patterns of significant responses were observed among soft and dry phenotypes. Soft phenotype showed significant differences in response to water treatments in plant height $(p<0.001)$, root fresh weight $(p<0.05)$ as well as number of dry leaves $(\mathrm{p}<0.05)$. The responses of dry phenotype to water availability were significant at all measured traits, except for root dry weight. The increase in the number of accelerated dry leaves, which is negatively correlated to water availability, was observed earlier for soft phenotypes at 25\% FC and 
$10 \%$ FC while delayed to $10 \%$ FC in dry phenotype's treatments. Dry phenotype responses were stronger than those of soft phenotype, as indicated by the level of significance as well as the stronger correlation relationships to changes in water availability (Table 1). An interaction effect of phenotype and water treatment was also detected, although with a different pattern, where differences were observed for root dry weight $(\mathrm{p}<0.05)$ and number of pinnae $(\mathrm{p}<0.01$; Table 2).

\section{Photosynthesis and gas exchange}

Compared to dry phenotype, the photosynthesis of soft was significantly higher at $10 \% \mathrm{FC}(\mathrm{p}<0.01$; Figure 1$)$. Water treatment at $50 \% \mathrm{FC}$ was seemed as optimum for gs in both phenotypes. Soft phenotype showed significantly $(\mathrm{p}<0.01)$ higher gs at all levels of water treatments (Figure 1), yet the difference increases as water supply decreases. Photosynthesis was found strongly driven by RUBP carboxylation at $100 \%$ and 50\% FC (Figure 2), however, the dry phenotype at $10 \% \mathrm{FC}$ showed a specific $\mathrm{Ci}_{\text {inflection }}$ (the $\mathrm{Ci}$ value where the Rubisco- and electron transport-limited portion of the curve intersects) between RUBP- saturated and RUBP-limited phases (Figure 2). At this water level, the dry phenotypes showed a signicantly lower photosynthetic rate $(\mathrm{p}<0.01)$ when compared to soft phenotypes.

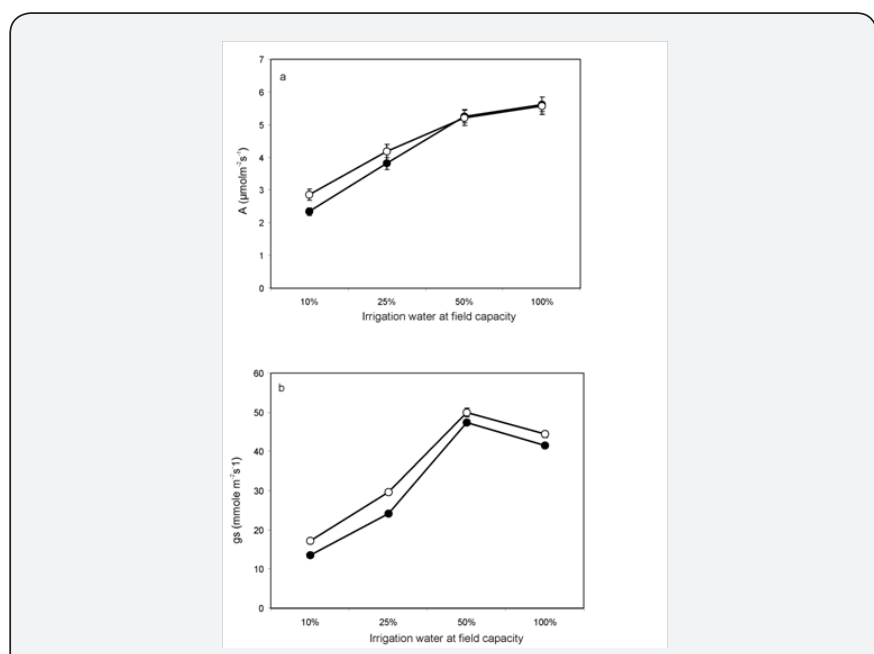

Figure 1: Responses of soft $(0)$ and dry $(\bullet)$ types of cultivars to water treatments: (a) photosynthesis $\left(A ; \mu \mathrm{molm}^{-2} \mathrm{~s}^{-1}\right)$ and $(\mathrm{b})$ stomatal conductance $\left(\mathrm{gs} ; \mathrm{mmole} \mathrm{m}^{-2} \mathrm{~s}^{-1}\right)$. Values are means $\pm \mathrm{SE}$.
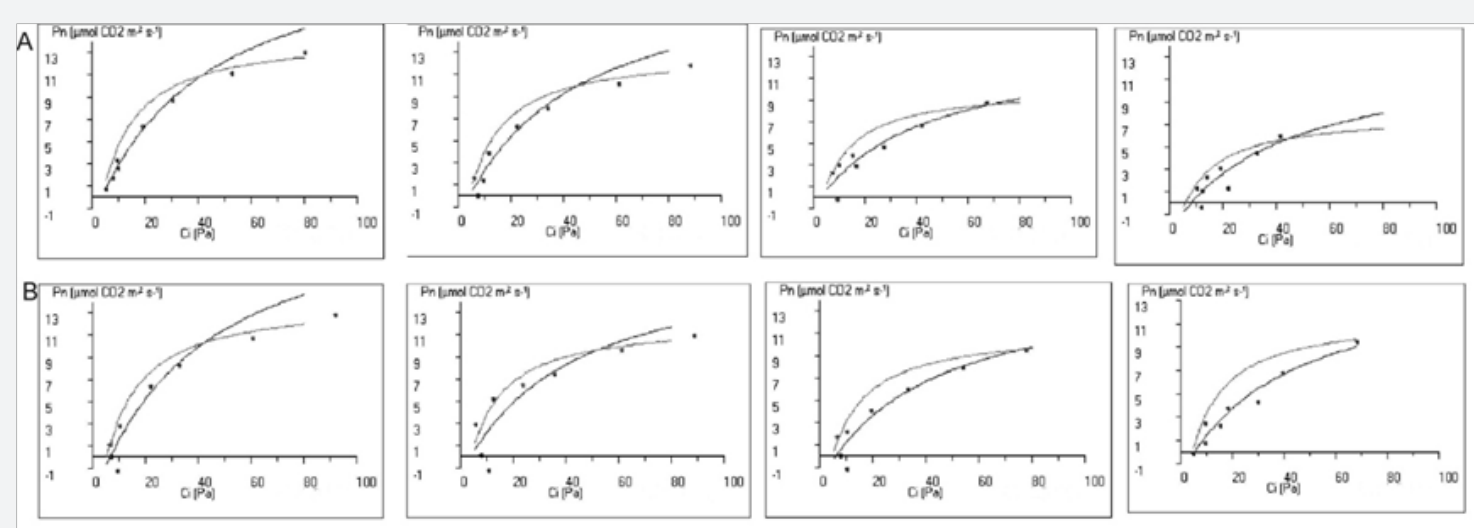

Figure 2: Response curve patterns of photosynthesis $(\mathrm{Pn})$ in $\mu \mathrm{molm}^{-2} \mathrm{~s}^{-1}$ versus $\mathrm{Ci}$ in $\mathrm{Pascal}(\mathrm{Pa})$ of $\left.\mathrm{A}\right)$ dry types, and $\left.\mathrm{B}\right)$ soft types. Each panel contains four different water levels, from left to right: $100 \%, 50 \%, 25 \%$ and $10 \%$ of field capacity.

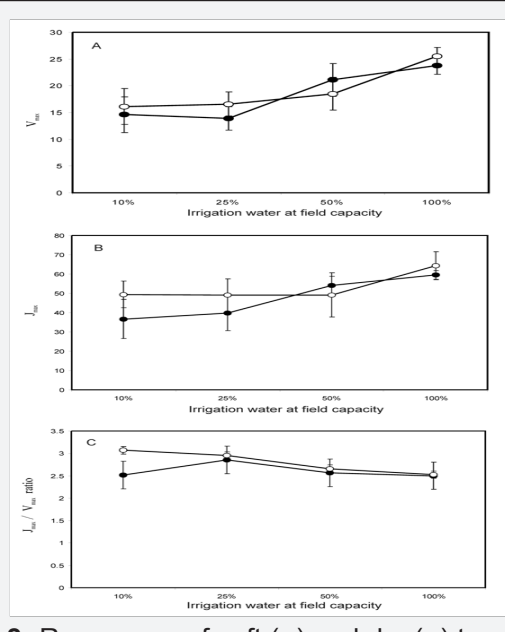

Figure 3: Responses of soft $(\circ)$ and dry $(\bullet)$ types of cultivars to different water levels in terms of (a) $\mathrm{V}_{\text {max }} \pm \mathrm{SE}$, (b) $\mathrm{J}_{\text {max }} \pm \mathrm{SE}$ and (c) $\mathrm{J}_{\max } / \mathrm{V}_{\max }$ ratio $\pm \mathrm{SE}$.
Compared to water treatment of $100 \% \mathrm{FC}$, the extent of $\mathrm{V}_{\max }$ reduction in $10 \% \mathrm{FC}$ equalled $37 \%$ and $39 \%$ in soft and dry phenotypes, respectively. Alteration of the two $V_{\max }$ (Figure 3) and $\mathrm{J}_{\max }$ parameters (Figure 3 ) resulted in slight gradual increase of the $\mathrm{J}_{\max } / \mathrm{V}_{\text {max }}$ ratio following reduced water supply from $100 \%$ to $25 \%$ (Figure 3); while significant $(\mathrm{p}<0.01)$ differentiation in responses among phenotypes observed at water treatment of $10 \% \mathrm{FC}$.

\section{Principal components analyses}

Patterns of similarity between individuals for growth responses (plant height, number of green and dry leaves, number of leaflets, root/shoot ratio and total biomass) revealed by two principal components. Two components were found to explain 73\% (PC1 $54.7 \%$; PC2 18.7\%) of the diversity of tested material. Number of green leaves (0.93), number of leaflets $(0.85)$ and total biomass (0.80) constituted the highest load on PC1, which explained 67\% of the total variance. Root/shoot ratio $(0.67 ; 59 \%)$ and plant height $(-0.53)$ constituted the highest load on PC2, which explained $84 \%$ 
of the total variance. Based on the first two principal components Figure 4 shows a distinguishable grouping pattern of cultivars belonging to the soft and dry phenotype for all treatments: $100 \%$ FC
$(\mathrm{Z}=-2.593, \mathrm{p}=0.008$; Figure 4), 50\% FC $(\mathrm{Z}=-2.828, \mathrm{p}=0.003$; Figure 4), $25 \%$ FC ( $\mathrm{Z}=-3.182, \mathrm{p}=0.000$; Figure 4$)$ and $10 \% \mathrm{FC}(\mathrm{Z}=-3.182$, $\mathrm{p}=0.000$; Figure 4).
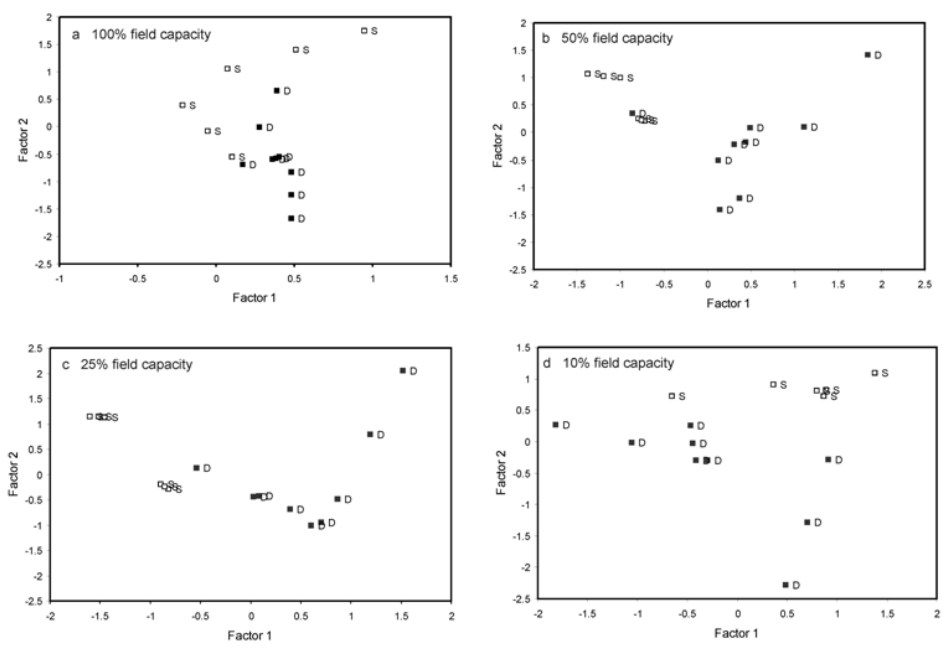

Figure 4: Principal component analyses for soft (S) and dry (D) types of date palm cultivars according to the first two components of growth and morphological traits in response to water treatments including (a) $100 \%$, (b) $50 \%$, (c) $25 \%$, and (d) $10 \%$ of field capacity.

Considering photosynthesis, gs, $\mathrm{Ci}$ and $\mathrm{Ca}$, two factors were found to explain 92\% (57.9\%; 33.8\%) of variation. Photosynthesis (0.94) and Ci (0.92) retained the highest load on PC1, which explained $50 \%$ and $49 \%$ of the total variance, respectively, and gs (0.99) constituted the highest load on PC2, which explained 97\% of the total variance. Based on the first two principal components Figure 5 shows a distinguishable pattern of cultivars belonging to the soft and dry phenotypes for water treatments of $25 \% \mathrm{FC}(\mathrm{Z}=$ $-6.639, \mathrm{p}=0.000$; Figure 5) and 10\% FC (Z=-6.709, $\mathrm{p}=0.000$; Figure $5)$.
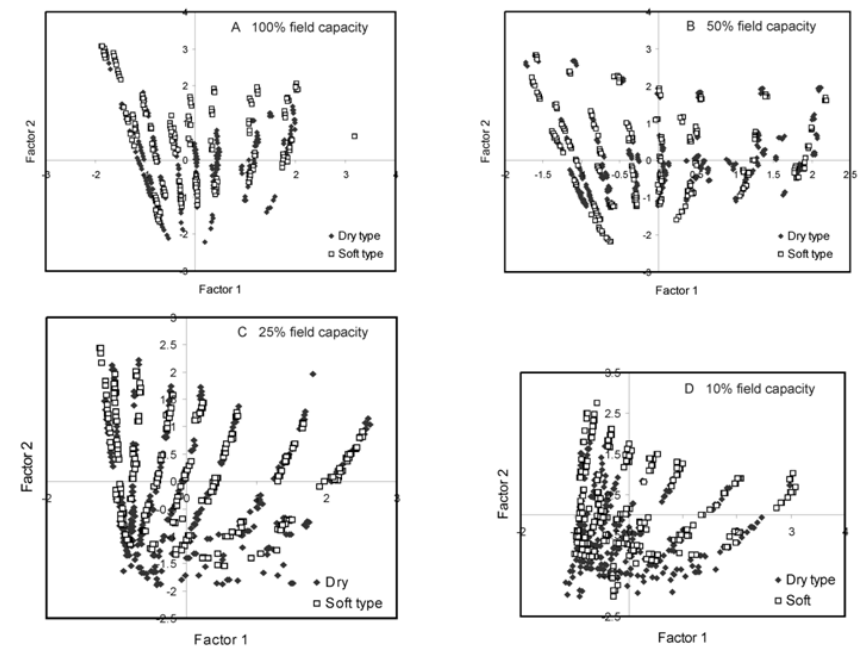

Figure 5: Principal component analyses of dry and soft types of date palm cultivars based on sub-stomatal $\mathrm{CO}_{2}(\mathrm{Ci})$, stomatal conductance and photosynthesis in response to eight levels of external $\mathrm{CO}_{2}$ supply and (A) $100 \%$, (B) $50 \%$, (C) $25 \%$, and (D) $10 \%$ of field capacity.

\section{Discussion}

Soft types tend to maximize their water uptake from soil by a slight increase in the root/shoot ratio at 50\% FC apparent from a significant increase in root dry weight and a slight decrease in shoot dry weight (Table 1). An increase in root to shoot ratio, attributable mainly to a reduction in shoot growth, has often been observed when water is limiting, when resource allocation to roots on the expense of shoots takes place $[10,17]$. The decrease in total biomass
(Table 1) under stress of $10 \%$ FC resulted from the direct slowing down of the whole growth and optimization of nutrient utilization [8], indicated by the decreased number of green leaves, induced by early senescence of older leaves (9), and the reduction in the number of photosynthesizing pinnae. The response of the tested phenotypes to water availability and their interaction showed different patterns. It was apparent that soft phenotypes are taller and have fewer numbers of pinnae (Table 1), but higher stomatal 
conductance (Figure 1). The more pronounced physiological adjustments that led to differentiation between soft and dry phenotypes included the ability of soft phenotype to fix more $\mathrm{CO}_{2}$ in the photosynthetic supply function (10\% FC; Figure 2), confirmed by the differences in the $\mathrm{J}_{\max } / \mathrm{V}_{\max }$ ratio (Figure 3) and resulting in a significant differences in photosynthesis (Figure 1).

The adjustments in different morphological traits were difficult to follow on an individual basis. We tried to resolve this observed complex pattern of responses in each group of date palms by applying the Principal Component Analysis (PCA). The PCA results confirmed the trend of responses observed when using basic statistical analyses as well as the traits of the A/Ci curve. Apparent dry and soft phenotype-specific responses were observed even at high levels of water supply when growth traits considered (Figure 4). Comparable results have been observed also in our previous study [6], when we assessed differences in growth traits of mother trees as well as compositional traits of fruits in a range of cultivars. Same trends among phenotypes detected when physiological traits (photosynthsis, gs and $\mathrm{J}_{\max } / \mathrm{V}_{\max }$ ratio) considered, yet enhanced by higher decrease in water supply (Figure $4 \& 5$ ). In line with these results [18] observed in Populus cathayana that drought inhibits photosynthetic capacity more in female genotypes than in male genotypes. Genotype-specific responses to water stress have been observed also in a range of other plant species [9,19-21].

\section{Conclusion}

The results obtained in this study emphasize the existence of considerable phenotype-specific responses of date palms to water availability. In line with current results and the previously reported genetic differentiation among soft and dry phenotypes of date palm we conclude that being soft or dry phenotype is supported by genetic drivers and represent adaptation move to different environments. These genetic resources have rich bases for adaptation and selection criteria to be considered especially for biodiversity enrichment and when new lands/regions to enter date palm culture.

\section{References}

1. Elshibli S, Korpelainen H (2011) Biodiversity in date palm: molecular markers as indicators. In: Jain SM, Al-Khayri JM, Johnson DV (Eds.), Date Palm Biotechnology. Springer Science+Business Media, Germany, pp. 371-406.

2. Osman AMA (1984) The performance of date palms in the Sudan. Acta Horticulturae 143: 231-237.

3. Zaid A, de Wet PF (2002) Origin, geographical distribution and nutritional values of date. In: Zaid A (Ed.), Date palm cultivation. Food and Agriculture Organisation of the United Nations, Rome, Italy, pp. 2944.

4. Barreveld WH (1993) Date palm products. FAO Agricultural services bulletin, No. 101. Food and Agricuture Organisation of the United Nations, Rome, Italy, p. 200.
5. Elshibli S, Korpelainen H (2009a) Biodiversity of date palms (Phoenix dactylifera L.) in Sudan: chemical, morphological and DNA polymorphisms of selected cultivars. Plant Genetic Resources: Characterization and Utilization 7: 194-203.

6. Elshibli S, Korpelainen H (2010) Identity of Date Palm (Phoenix dactylifera L.) Germplasm in Sudan: From the Morphology and Chemical Characters to Molecular Markers. Acta Horticulturae 859: 143-153.

7. Elshibli S, Korpelainen H (2009b) Excess heterozygosity and scarce genetic differentiation in the populations of Phoenix dactylifera L.: human impact or ecological determinants. Plant Genetic Resources: Characterization and Utilization 7: 95-104.

8. Osorio J, Osorio ML, Chaves MM, Pereira JS (1998) Water defecits are more important in delaying growth than in changing patterns of carbon allocation in Eucalyptus globulus. Tree Physiology 18(6): 363-373.

9. Munne-Bosch S, Alerge L (2004) Die and let live: leaf senescense contributes to plant survival under drought stress. Functional Plant Biology 31: 203-216.

10. Susiluoto S, Berninger F (2007) Interactions between morphological and physiological drought responses in Eucalyptus microtheca. Silva Fennica 41: 221-233.

11. Lambers H, Chapin FS, Pons TL (2008) Plant Physiological Ecology. $\left(2^{\text {nd }}\right.$ edn), Springer, New York, USA, p. 604.

12. Elshibli S, Elshibli ME, Korpelainen H (2016) Growth and photosynthetic $\mathrm{CO}_{2}$ responses of date palm plants to water availability. Emirates Journal of Food and Agriculture. Emir J Food Agric 28(1): 58-65.

13. Farquhar GD, von Caemmerer S, Berry JA (1980) A biochemical model of photosynthetic $\mathrm{CO}_{2}$ assimilation in leaves of $\mathrm{C}_{3}$ species. Planta 149(1): 78-90.

14. Von Caemmerer S, Farquhar GD (1981) Some relationships between the biochemistry of photosynthesis and the gas exchange rates of leaves. Planta 153(4): 376-387.

15. Sharkey TD (1985) Photosynthesis of intact leaves of $C_{3}$ plants: physics, physiology and rate limitations. Botanical Review 51(1): 53-105.

16. Drake BG, Gonzalez-Meler MA, Long SP (1997) More efficient plants: a consequence of rising atmospheric $\mathrm{CO}_{2}$. Annual Review of Plant Physiology and Plant Molecular Biology 48: 609-639.

17. Sharp RE, Davies WJ (1979) Solute regulation and growth by roots and shoots of water-stressed maize plants. Planta 147(1): 43-49.

18. Xu, X., G. Peng, C. Wu, H. Korpelainen and C. Li. 2008. Drought inhibits photosynthetic capacity more in females than in males of Populus cathayana. Tree Physiology 28: 1751-1759.

19. Massonnet C, Costes E, Rambal S, Dreyer E, Regnard J (2007) Stomatal regulation of photosynthesis in apple leaves: evidence for different water-use strategies between two cultivars. Annals of Botany 100(6): $1347-1356$.

20. Meier IC, Leuschner C (2008) Genotypic variation and phenotypic plasticity in the drought response of fine roots of European beech. Tree Physiology 28(2): 297-309.

21. Izanloo A, Condon AG, Langridge P, Tester M, Schnurbusch T (2008) Different mechanisms of adaptation to cyclic water stress in two south Australian bread wheat cultivars. J Exp Bot 59(12): 3327-3346. 
This work is licensed under Creative Commons Attribution 4.0 License DOI: 10.19080/ARTOAJ.2017.05.555665

\section{Your next submission with Juniper Publishers} will reach you the below assets

- Quality Editorial service

- Swift Peer Review

- Reprints availability

- E-prints Service

- Manuscript Podcast for convenient understanding

- Global attainment for your research

- Manuscript accessibility in different formats ( Pdf, E-pub, Full Text, Audio)

- Unceasing customer service

Track the below URL for one-step submission https://juniperpublishers.com/online-submission.php 